\title{
Article \\ Characteristics of Swell-like Waves in the East Coast of Korea Using Atmospheric and Wave Hindcast Data
}

\author{
Sang-Hun Jeong ${ }^{1,2}$, Ki-Young Heo $^{1, *}$, Jun-Hyeok Son ${ }^{1} \mathbb{C}$, Young-Heon Jo ${ }^{2}{ }^{\oplus}$, Jin-Yong Choi ${ }^{1}$ and Jae-Il Kwon ${ }^{1}$ \\ 1 Marine Disaster Research Center, Korea Institute of Ocean Science \& Technology, Busan 49111, Korea; \\ jsh5481@kiost.ac.kr (S.-H.J.); j-hson@kiost.ac.kr (J.-H.S.); joyoung@pusan.ac.kr (Y.-H.J.); \\ dol76@kiost.ac.kr (J.-Y.C.); jikwon@kiost.ac.kr (J.-I.K.) \\ 2 BK21 School of Earth Environmental Systems, Pusan National University, Busan 46241, Korea \\ * Correspondence: kyheo21@kiost.ac.kr; Tel.: +82-051-664-3704
}

\section{check for}

updates

Citation: Jeong, S.-H.; Heo, K.-Y.;

Son, J.-H.; Jo, Y.-H.; Choi, J.-Y.;

Kwon, J.-I. Characteristics of

Swell-like Waves in the East Coast of Korea Using Atmospheric and Wave Hindcast Data. Atmosphere 2022, 13, 286. https://doi.org/10.3390/ atmos13020286

Academic Editors: Galina Surkova, Alexander Olchev and Jens Hesselbjerg Christensen

Received: 13 December 2021

Accepted: 7 February 2022

Published: 8 February 2022

Publisher's Note: MDPI stays neutral with regard to jurisdictional claims in published maps and institutional affiliations.

Copyright: (c) 2022 by the authors. Licensee MDPI, Basel, Switzerland. This article is an open access article distributed under the terms and conditions of the Creative Commons Attribution (CC BY) license (https:// creativecommons.org/licenses/by/ $4.0 /)$.

\begin{abstract}
The long-term trend of swell-like waves invading the east coast of Korea was identified by using observations and hindcast data from 1979 to 2016. We defined a swell-like wave as a wave with a height of $2 \mathrm{~m}$ and a peak period of $10 \mathrm{~s}$ on the basis of a literature review of human casualties and property damage in the region. In total, 179 swell-like wave cases were detected from 1979 to 2016, with 132 cases caused by extratropical cyclones (ETCs). The track density analysis indicated that the ETCs were mainly generated on the east coast of China, over the East/Japan Sea, and over the Kuroshio-Oyashio extension region and then moved northeast. This reflects the prevailing wind direction, which was the most significant factor in generating the swell-like waves. The number of swell-like waves has been significantly increasing since the 2000s. This increasing trend of swell-like waves is linked with the synoptic eddy activity with a correlation of 0.53 . They were associated with the reversed meridional gradient of surface air temperature and the consequent negative vertical wind shear anomaly near $40^{\circ} \mathrm{N}$.
\end{abstract}

Keywords: swell-like wave; extratropical cyclone; track density; hindcast; cyclone tracking

\section{Introduction}

Anomalously high wind waves, mainly generated in the East/Japan Sea (EJS), frequently occur due to extratropical cyclones (ETCs) passing through the EJS during autumn and winter [1-4]. Strong winds accompanied by intense storms also produce long surface gravity waves that radiate out of their generation area [5,6]. High wind waves have been observed through in situ observation or spaceborne remote sensing $[7,8]$. Kitaide [1] demonstrated that abnormal high swell waves (or a Yorimawari Waves) are generated due to the solid north-easterly winds formed by a quasi-stationary low-pressure system. Utsunomiya et al. [9] reported that waves with a significant wave height of $\geq 2 \mathrm{~m}$, significant wave period of $\geq 10 \mathrm{~s}$, and a wave steepness of $\leq 0.02$ can be classified as a Yorimawari Wave. Jeong et al. [10] and Oh et al. [11] demonstrated that these waves, called swell-like waves, frequently occur under clear weather conditions over the coastal region because they originate from the central or eastern EJS. These swell-like waves usually last two to three days in winter and can cause property damage and human casualties in coastal areas.

Damage caused by swell-like waves has been increasingly detected in recent years, and includes the destruction of breakwaters, water yards, and fishing boats, flooded roads, vehicles, and buildings, and a range of associated costs for recovery and compensation. These problems trigger severe disruption to offshore operations and port activities. From November 2005 to January 2016, the amount of ocean swell-induced damage in Gangwon province reached nearly USD five million [12].

Swell-like waves are frequently observed along the east coast of Korea, located to the west of the EJS $[10,11,13]$. Jeong et al. [10] found that strong winds generated swell-like waves that propagated across the EJS to the coast in this region. Jang et al. [13] concluded 
that explosive cyclones accompanied by firm and persistent winds are the drivers of swelllike waves. These explosive ETCs have been also detected over the EJS and the northwest Pacific near the Kuroshio Current [14,15]. Heo et al. [16] examined the mechanisms and conditions conducive to explosive cyclones and abnormal storm waves in the EJS. Jeong and Oh [17] also studied swell-like waves that caused casualties on the east coast of Korea, finding that most cases occurred in the winter between October and February.

Notably, most studies have concluded that the driver of swell-like waves is ETCs, which occur mainly in winter with a strong wind field. Furthermore, previous studies have reported that part of the total ETC events develop into explosive cyclones, thereby producing stronger waves [16]. East Asia has favorable conditions for the development of ETCs as the upper-tropospheric wave action is in the active phase and the east coast of Asia is located in the climatological frequency maxima of the Warm Conveyor Belt [18-20]. In addition, ETCs are frequently detected in marine areas of the Northern Hemisphere such as the North Atlantic, North Pacific, and inland of East Asia [19]. Most previous studies have been conducted only for certain periods or specific cases. Several studies have confirmed that ETCs are essential for generating swell-like waves in the cold season $[8,10,11,13,17]$. However, the drivers of the recent increase in the swell-like waves are not fully understood, especially at the decadal and multi-decadal timescales.

The main aim of this study was to examine the long-term trend of the occurrence of swell-like waves on the East coast of Korea by using in situ data, high-resolution hindcasts, and reanalysis. We: (a) produced high-resolution atmospheric and wave hindcasts, (b) determined the occurrence trends and characteristics of swell-like waves from the observations, and (c) identified the cases of swell-like waves from the hindcasts. Finally, via reanalysis, we used the cyclone tracking algorithm to analyze the occurrence and movement pattern of ETCs, which represent the main driver of swell-like waves.

\section{Data and Method}

Our methodology consisted of three steps. First, accidents caused by swell-like waves on the east coast of Korea were investigated through a literature review. To help define what should be considered an accident involving a swell-like wave causing damage, we investigated cases in which human life and property were damaged due to swell activity. Each case was collected from media, articles, and government reports from October 2005 to August 2018. For a more accurate definition of swell-like waves, the cases were investigated over a longer time series than those for the hindcasts. We retrieved the characteristics of waves that can theoretically damage the coast by using the observations and hindcast for each accident case. Second, we used these results to identify cases of wave intrusions in the Korean coast in 1979-2016. Third, a cyclone tracking algorithm was applied to characterize the ETCs, which are known to be the cause of swell-like waves. Lastly, the long-term characteristics of swell-like waves were examined alongside the results of the cyclone tracking algorithm, and eddy activities were analyzed to elucidate the long-term characteristics.

\subsection{Data}

We utilized the observation data from five buoys of the Korean Meteorological Administration (KMA) and the Korea Hydrographic and Oceanographic Agency (KHOA), denoted as DH, UL, PH, E01, and E02 in Figure 1b. Furthermore, we observed wave characteristics by using acoustic directional wave and current profilers to evaluate ocean swell definition and to evaluate hindcasts, denoted as SC, MB, WJ, YI, and SR (Figure 1b). Table 1 summarizes the information on the observation data. Finally, ERA-Interim [21] was used to analyze eddy activities, to identify cyclone tracking, and to provide atmospheric hindcast's initial and boundary conditions. 
(a)

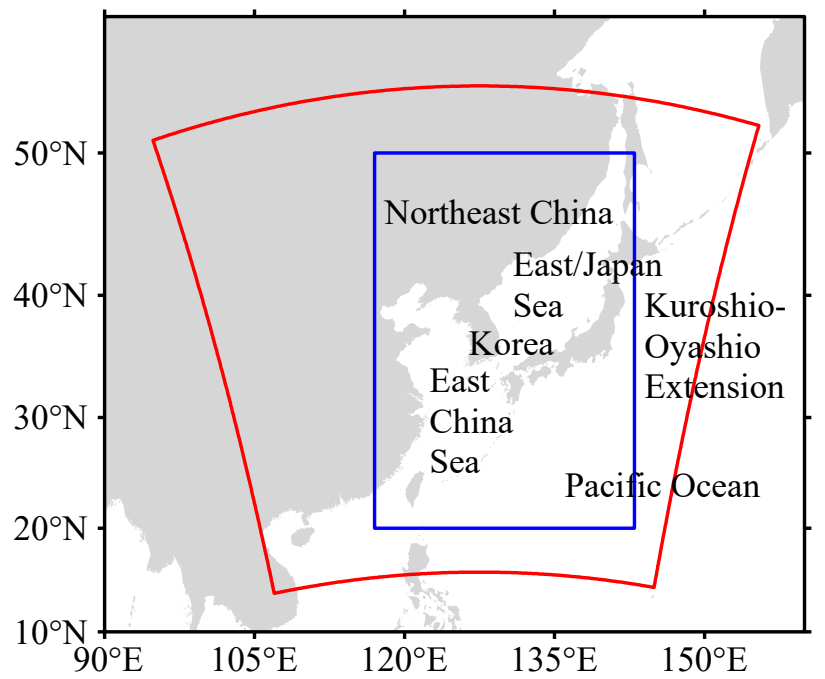

(b)

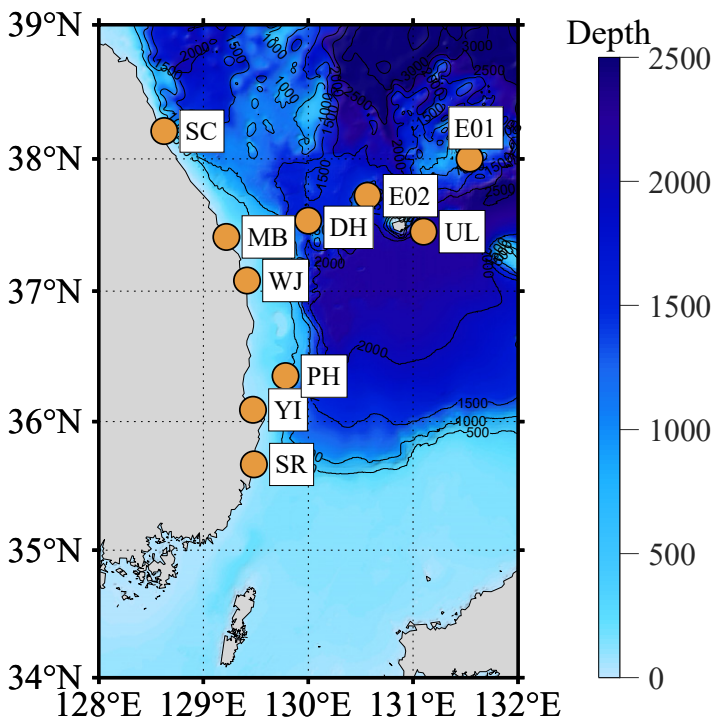

Figure 1. Representation of the study area showing (a) the atmospheric (red box) and wave (blue box) model domains and (b) the east coast of Korea, along with the bathymetry and observation sites used in this study (see Table 1).

Table 1. The specific information of observations. The stations of SC, MB, WJ, HP, YI, and SR are operated using an acoustic wave and current profiler (AWAC), and the others are operated using buoys. For AWAC stations, installation depth is provided.

\begin{tabular}{cccccc}
\hline Name & Organization & Location & Component & $\begin{array}{c}\text { Measurement } \\
\text { Duration }\end{array}$ & $\begin{array}{c}\text { Water Depth } \\
(\mathbf{m})\end{array}$ \\
\hline Sokcho (SC) & KIOST & $38.20^{\circ} \mathrm{N}, 128.63^{\circ} \mathrm{E}$ & & October 2010 December 2016 & 15.0 \\
Maengbang (MB) & KIOST & $37.41^{\circ} \mathrm{N}, 129.22^{\circ} \mathrm{E}$ & Current & September 2014 December 2016 & 25.9 \\
Wuljin (WJ) & KIOST & $37.07^{\circ} \mathrm{N}, 129.42^{\circ} \mathrm{E}$ & $\mathrm{H}_{\mathrm{m} 0}$ & September 2014 December 2016 & 18.7 \\
Hupo (HP) & KIOST & $36.70^{\circ} \mathrm{N}, 129.48^{\circ} \mathrm{E}$ & $\mathrm{T}_{02}$ & December 2011 March 2014 & 17.5 \\
Youngil (YI) & KIOST & $36.09^{\circ} \mathrm{N}, 129.47^{\circ} \mathrm{E}$ & $\mathrm{T}_{\mathrm{p}}$ & August 2010 August 2015 & 24.5 \\
Sureummal (SR) & KIOST & $35.67^{\circ} \mathrm{N}, 129.48^{\circ} \mathrm{E}$ & & July 2014 December 2016 & 32.1 \\
\hline Donghae (DH) & KMA & $37.53^{\circ} \mathrm{N}, 130.00^{\circ} \mathrm{E}$ & Wind & January 2005 December 2016 & - \\
Ulleung (UL) & KMA & $37.45^{\circ} \mathrm{N}, 131.10^{\circ} \mathrm{E}$ & $\mathrm{SST}$ & December 2011 December 2016 & - \\
Pohang (PH) & KMA & $36.35^{\circ} \mathrm{N}, 129.78^{\circ} \mathrm{E}$ & November 2008 December 2016 & - \\
Ulleung NE (E01) & KHOA & $38.00^{\circ} \mathrm{N}, 131.54^{\circ} \mathrm{E}$ & $\mathrm{H}_{\mathrm{S}}$ & October 2012 December 2016 & - \\
Ulleung NS (E02) & KHOA & $37.72^{\circ} \mathrm{N}, 130.56^{\circ} \mathrm{E}$ & $\mathrm{T}_{\mathrm{m}}$ & August 2014 December 2016 & - \\
\hline
\end{tabular}

\subsection{Model for Atmospheric and Wave Hindcast}

We produced atmospheric and wave hindcasts from 1979 to 2016. To retrieve a comprehensive atmospheric hindcast, the Advanced Research-Weather Research and Forecast model (WRF-ARW) [22] version 3.7 and its variational data assimilation system (WRFDA), developed by the National Center of Atmospheric Research (NCAR), were utilized [23,24]. The three-dimensional variational data assimilation technique was applied to improve the model's initial conditions and to generate the final high-resolution hindcast. The model incorporates fully incompressible nonhydrostatic equations in synergy with terrain-following vertical coordinates. The model area was about $20-50^{\circ} \mathrm{N}, 117-143^{\circ} \mathrm{E}$, the horizontal resolution of the domain was $10 \mathrm{~km}$ with $435 \times 435$ grids, and the vertical resolution was 60 layers from the surface to a $50 \mathrm{hPa}$ level (Figure 1a). The instantaneous model outputs were saved every hour. We used the Yonsei University (YSU) planetary boundary layer scheme [25], Noah land surface model [26], and Kain-Fritsch cumulus parameterization scheme [27]. This model applied the Dudhia short-wave and rapid-radiative-transfer- 
model (RRTM) long-wave radiation scheme [28], and the WRF single moment 6 class [29]. Table 2 summarizes the applied model configuration parameters and physical schemes.

Table 2. Overview of WRF model configuration for the experiments.

\begin{tabular}{cc}
\hline Model Used & WRF v.3.7.1 \\
\hline Initial and boundary conditions & ERA-Interim $0.75^{\circ} \times 0.75^{\circ}(6-\mathrm{h}$ interval) \\
Horizontal and vertical resolution & $10 \mathrm{~km} \times 10 \mathrm{~km}, 60$ layers to $50 \mathrm{hPa}$ \\
Horizontal grid points in X-Y direction & $435 \times 435$ \\
Period of integration & $30 \mathrm{~h}$ (including $6 \mathrm{~h}$ spin-up) \\
Cumulus parameterization schemes & Kain-Fritsch scheme \\
PBL parameterization schemes & YSU PBL scheme \\
Microphysics parameterization & WSM 6-class graupel scheme \\
schemes & Dudhia short-wave and RRTM long-wave \\
Radiation parameterization scheme & radiation scheme \\
Surface layer scheme & Monin-Obukhov similarity theory \\
Land-surface scheme & Noah land surface scheme \\
\hline
\end{tabular}

The SWAN (Simulation Waves Nearshore, [30]) model version 41.10 was used for the wave hindcast in the model area with grids of $313 \times 361$ and $1 / 12^{\circ}$ resolution (Figure $1 \mathrm{a}$ ). We also applied the Korea coastal precision grid bathymetry, provided by KHOA with the General Bathymetric Chart of the Oceans (GEBCO) data [31]. The two-dimensional energy spectrum was composed of 72 wave directions. The number of frequencies are 25 (0.04-0.40 Hz range), and the time interval was set to $300 \mathrm{~s}$. In this study, the spectral area was reduced to shorten the computing time because we determined whether the swell-like wave condition was satisfied only when the waves in the SWAN model were of a significant height. It was calculated through 50 iterations for $99 \%$ convergence every hour, and the friction coefficient was set to $0.038 \mathrm{~m}^{2} \mathrm{~s}^{-3}$ in the JONSWAP formulation [32]. The rest of the settings were configured as the default.

\subsection{Identification and Tracking of ETCS}

In this study, a cyclone tracking algorithm was used to quantify the characteristics of ETCs affecting the generation of swell-like waves. The cyclone tracking algorithm defines and tracks cyclones. We utilized relative vorticity and sea level pressure to determine the cyclones; the detailed description of the applied method can be found in Flaounas et al. [33] and $\mathrm{Lu}$ [34]. We detected the cyclonic circulation through the relative vorticity at the $850 \mathrm{hPa}$ level and defined the size of the cyclone as the enclosed contours of the sea level pressure field. We retrieved the relative vorticity and sea level pressure from the ERA-Interim data with a horizontal resolution of $0.75^{\circ} \times 0.75^{\circ}$ and a time resolution of $6 \mathrm{~h}$. The $850 \mathrm{hPa}$ relative vorticity and sea level pressure field were smoothed to remove the small-scale relative vorticity not related to synoptic-scale cyclone development and movement. We utilized field $9 \times 9$ grid point filtering, where each field was smoothed into a $6.75^{\circ} \times 6.75^{\circ}$ area.

Figure 2 shows an example of cyclone detection at 00 UTC on 4 January 1980. We used the relative vorticity threshold of $3 \times 10^{-5} \mathrm{~s}^{-1}$ to identify the centers of the cyclones following Flaounas et al. [33] (Figure 2a). Furthermore, the sea level pressure field was analyzed to understand whether these areas had been caused by cyclones or by local wind shear. Figure $2 \mathrm{~b}$ shows the valid closed contours of the sea level pressure field with a $2 \mathrm{hPa}$ interval. High-pressure systems and cyclones, that is, pairs of closed contours that should be distinguished, are also shown in Figure 2b. Note that Figure 2c shows that a cyclone was detected if a valid closed contour satisfying the threshold in the relative vorticity field was detected in the region. The enclosed contour may be small enough not to identify a cyclonic center in the grid points $\left(0.75^{\circ} \times 0.75^{\circ}\right)$, too large or abnormal elliptical shapes irrelevant to cyclonic vortices. Due to this, we set the minimum value of the long axis to $100 \mathrm{~km}$ (about $1^{\circ}$ mid-latitude) and the maximum value to $1000 \mathrm{~km}$. Then, only one closed contour or a group of several closed contours may potentially exist. We deduced that a 
cyclone was detected if $>20 \%$ of the grid satisfying the relative vorticity threshold was included in the innermost contour. The external boundary of a cyclone was defined as the first closed curve with an area of $3.14 \times 10^{6} \mathrm{~km}^{2}$ (equivalent circular radius of $1000 \mathrm{~km}$ ) or less, according to $\mathrm{Lu}$ [34]. Figure $2 \mathrm{~d}$ shows two cyclones that satisfy all such conditions. A solid red line represents the boundary of each cyclone, and the minimum point of sea level pressure inside the closed contour was determined as the cyclonic center. At this time, the minimum point of sea level pressure was calculated from the original field.

(a)

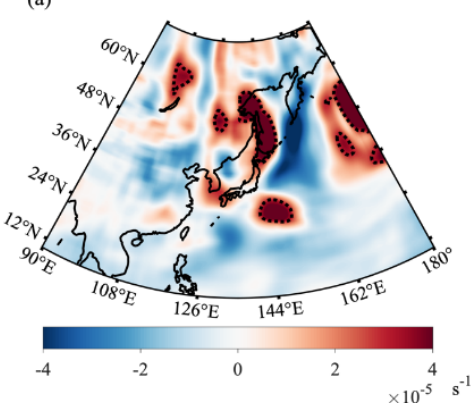

(c)

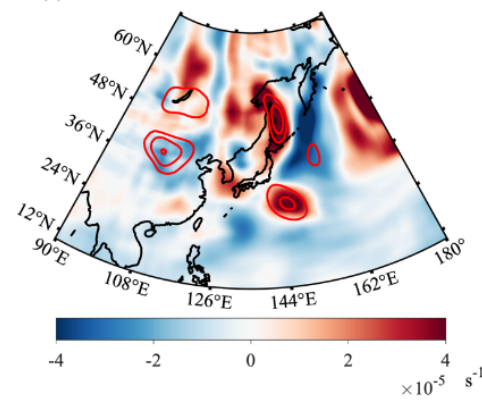

(b)

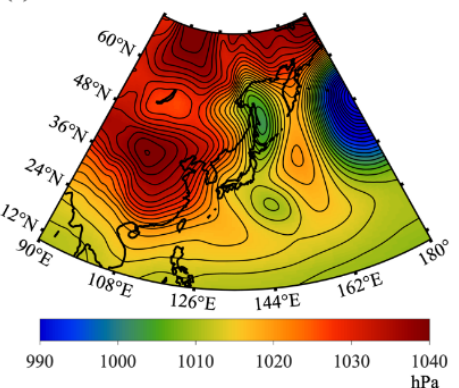

(d)

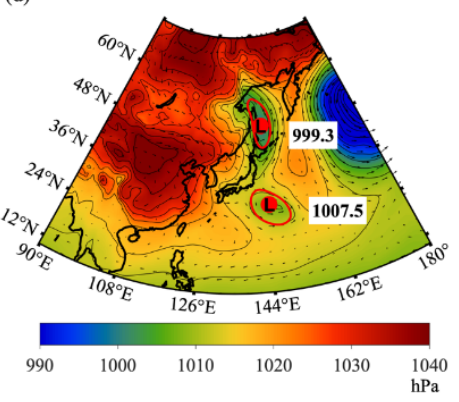

Figure 2. Example of cyclone identification and application of cyclone tracking algorithm at 00 UTC 4 January 1980. (a) Smoothed horizontal relative vorticity at $500 \mathrm{hPa}$ level. The dotted line contour means the area above the threshold $\left(3 \times 10^{-5} \mathrm{~s}^{-1}\right)$. (b) Smoothed sea level pressure field and isobars. (c) Smoothed relative vorticity field and closed isobars (red line). (d) Original sea level pressure and outermost contour (red line) of the extracted cyclone. Red dots with the mark " $\mathrm{L}$ " reflect the cyclone center.

The cyclones extracted through this approach were tracked every $6 \mathrm{~h}$. The first criterion is whether each cyclone overlaps its outer boundary within $6 \mathrm{~h}$ or not. If an external boundary overlaps, it is considered to be the same cyclone. If there is no overlap, it can be still classified as the same cyclone if the movement speed of the low pressure is $<650 \mathrm{~km}$ within $6 \mathrm{~h}$. If there were two or more overlapping cyclones, we decided whether to merge or to split them based on distance, pressure difference, and hardness. If multiple cyclones overlapped with a closed candidate, it was connected to the cyclone where the difference in central pressure was minimal. If a closed candidate satisfied the distance threshold for multiple cyclones, it was connected to the shortest one. The remaining cyclones were merged, and the record updated to the current timestep was saved. If there were multiple closed candidates that could be connected to the tracking cyclone, the one with the smallest pressure difference was connected to the cyclone. The others were considered potentially split and were tracked at the next timestep. Note that we selected only those tracks with lifetimes longer than $12 \mathrm{~h}$.

The cyclone track density was quantified from the cyclonic grid points in the outermost contour of the cyclone [34]. The cyclonic track density (TD) was expressed as shown in Equation (1):

$$
\text { Track Density }\left(\mathrm{TD}_{\mathrm{j}}\right)=\sum_{\mathrm{i}=1}^{\mathrm{N}} \mathrm{C}_{\mathrm{i}} /(\mathrm{N} \times \mathrm{T})
$$


where $C_{i}$ (number of cyclone; 0 or 1 ) denotes the number of times the jth grid point is affected by the cyclone at the ith time step. $\mathrm{N}$ is the total number of time steps in a given period. Note that TD is a relative number in a given period. The time step in this study was $6 \mathrm{~h}$, so $\mathrm{T}$ was used to convert TD to a unit of daytime $(\mathrm{T}=4)$.

\subsection{Wind Activity Index}

The surface wind perturbation affecting the generation of the swell-like wave (that arrived in the eastern side of Korea) is strongly linked with the atmospheric synoptic eddy activity. The synoptic eddy activity was calculated based on [35] by using Equation (2):

$$
\left(\mathrm{U}^{\prime 2}+\mathrm{V}^{\prime 2}\right) / 2 .
$$

Here, $\mathrm{U}^{\prime}$ and $\mathrm{V}^{\prime}$ are bandpass-filtered zonal and meridional wind, respectively. Lanczos filters with a weight of 9 (17) were used for the 2-8 (9-21) days bandpass filtering (e.g., the weight 9 is calculated as $4 \times 2+1=9$ ) for analyzing the horizontal wind at $500 \mathrm{hPa}$ within the ERA-Interim reanalysis data. Over mid-latitudes, eastward-propagating high-frequency traveling synoptic waves were projected on the 2-8 days window [36], and slower intermediate timescale waves were projected on the 9-21 days bandpass filtering window. The slower waves included the type of atmospheric blocking event [37].

\section{Results}

\subsection{Characteristics of Swell-like Waves on the East Coast of Korea}

The damage to human life and property caused by swell-like waves on the east coast of Korea was investigated in the period of October 2005-August 2018. During this period, there were 75 accidents on the east coast, causing 52 fatalities. Casualties occurred mainly on beaches, breakwaters, and rocky shores. The property damage was mostly related to the damages of breakwaters, coastal roads, and coastal facilities, flooding of moored ships and parked vehicles, and local government's recovery costs due to coastal erosion. The literature review was used to analyze the accident frequency at monthly and annual temporal resolution. To elucidate the effective occurrence trend, we counted the number of accidents that occurred at multiple points on the same day as one.

At least two incidents have been continuously reported each year except 2010 (Figure 3a). They occurred most frequently in the following order: summer, autumn, winter, and spring (Figure $3 b$ ). Figure $3 c$ shows the significant wave height and peak period during the accident. These data were used for the analysis by using the in situ data and hindcast results. If the accident time was ambiguous, the maximum value of the significant wave height on the day of the accident was selected. Without observed data, the hindcast results were used. For the accidents occurring all over the east coast of Korea, the maximum value observed at the time was utilized.

In some cases, the wave height and period were too low for the wave to be considered a swell-like wave. Some cases reported by the media may not have been verified. Most of such cases occurred in places where leisure activities were common, such as the beaches, rocky coasts, and nearshore areas (Figure 3c). Accidents in these places may have been caused by simple human error. However, a relatively high wave energy may have been involved in human injuries at breakwaters or damage to coastal structures.

Property damage occurred under the conditions of a significant wave height of $\sim 2 \mathrm{~m}$ or more and a peak time of $\sim 10 \mathrm{~s}$ or more in all but one case. This finding aligns with previous studies, especially Oh et al. [11]. They suggested that some swell-like waves were slightly larger than the typical large swell of $3 \mathrm{~m}$ or more, with a peak period of more than $9 \mathrm{~s}$. Most human casualties were reported when wave heights were $2 \mathrm{~m}$ or less because local governments restrict coastal activities in high-risk situations [12]. These results suggest that on the east coast of Korea, waves with a height of $2 \mathrm{~m}$ or more and a peak period of $10 \mathrm{~s}$ or more should be classified as swell-like waves. 
(a)

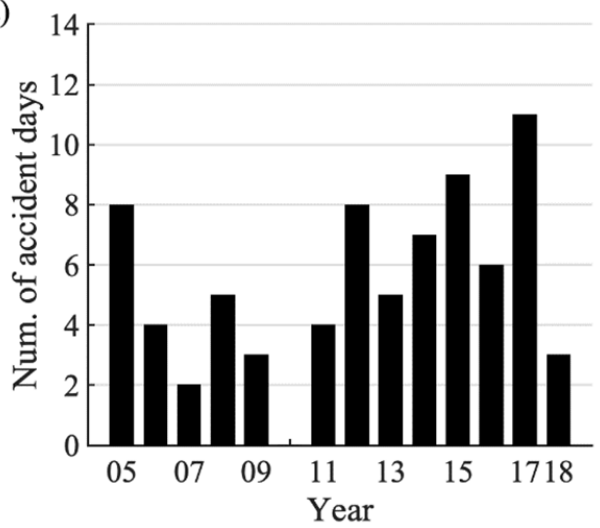

(b)

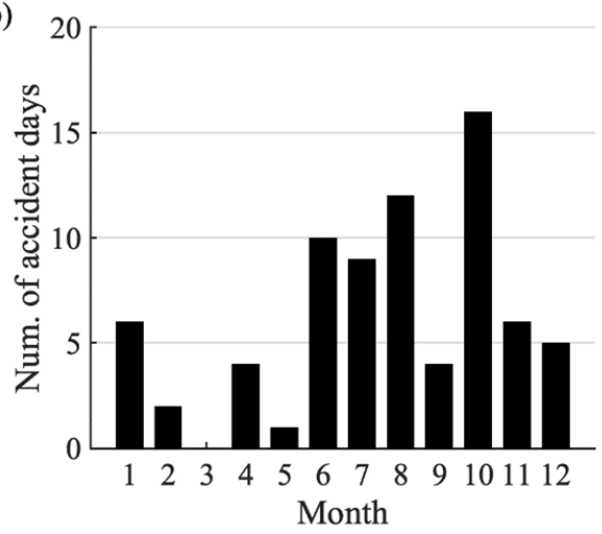

(c)

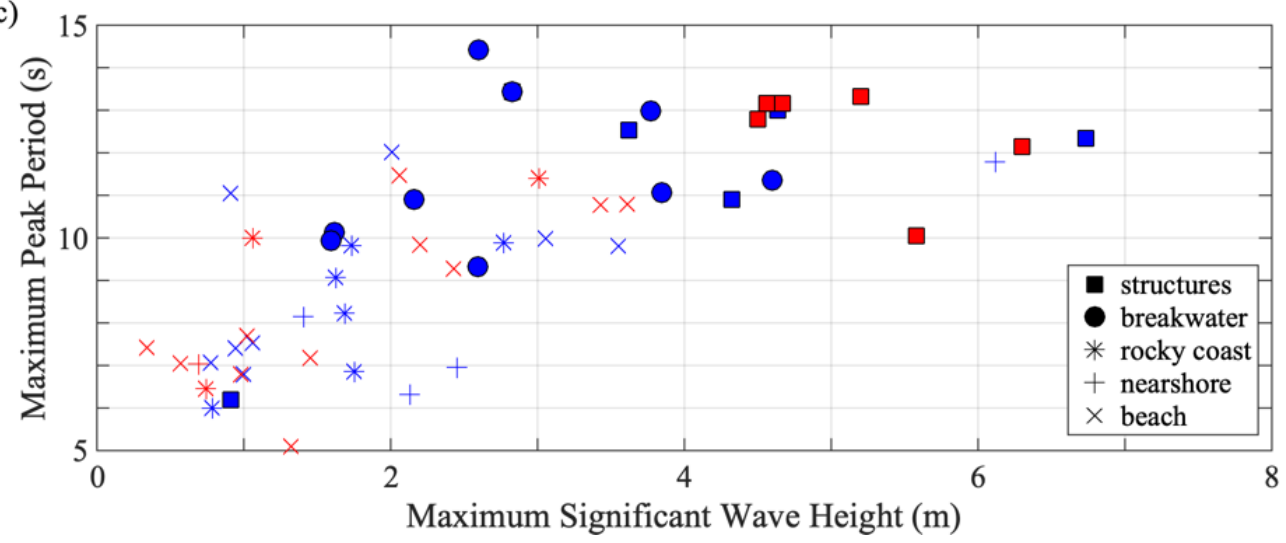

Figure 3. (a) Number of accidents by year identified in the literature review. (b) Number of events per month. (c) The maximum significant wave height and maximum peak period from the observations (red) and hindcasts (blue) at each location of accident. A specific marker has been used to reflect the classification of each accident and source.

\subsection{Model Assessment of $10 \mathrm{~m}$ Wind and Wave}

We used the following statistical metrics for the comparison of hindcast data with observations: MB (Mean Bias), RMSE (Root-Mean-Square Error), Index of Agreement (IOA) [38,39], and Complex Correlation (CC Magnitude, CC Phase lag) [40]. The equations applied for calculating these metrics are shown below:

$$
\begin{gathered}
\mathrm{MB}=\frac{1}{\mathrm{~N}} \sum_{\mathrm{i}=1}^{\mathrm{N}}\left(\mathrm{P}_{\mathrm{i}}-\mathrm{O}_{\mathrm{i}}\right) \\
\mathrm{MSE}=\sqrt{\frac{1}{\mathrm{~N}} \sum_{\mathrm{i}=1}^{\mathrm{N}}\left(\mathrm{P}_{\mathrm{i}}-\mathrm{O}_{\mathrm{i}}\right)^{2}} \\
\mathrm{IOA}=1-\left[\frac{\sum_{\mathrm{i}=1}^{\mathrm{N}}\left(\mathrm{P}_{\mathrm{i}}-\mathrm{O}_{\mathrm{i}}\right)^{2}}{\sum_{\mathrm{i}=1}^{\mathrm{N}}\left(\left|\mathrm{P}_{\mathrm{i}}-\overline{\mathrm{O}}\right|+\left|\mathrm{O}_{\mathrm{i}}-\overline{\mathrm{O}}\right|\right)^{2}}\right] \\
\mathrm{CC} \text { Magnitude }=|\rho|=\sqrt{[\operatorname{Re}(\rho)]^{2}[\operatorname{Im}(\rho)]^{2}} \\
\rho=\frac{\left\langle\mathrm{V}_{\mathrm{p}} \times \mathrm{V}_{\mathrm{o}}^{*}\right\rangle}{\sqrt{\left\langle\mathrm{V}_{\mathrm{p}} \times \mathrm{V}_{\mathrm{p}}^{*}\right\rangle\left\langle\mathrm{V}_{\mathrm{o}} \times \mathrm{V}_{\mathrm{o}}^{*}\right\rangle}}, \mathrm{V}=\mathrm{u}+\mathrm{iv}
\end{gathered}
$$


$\mathrm{N}$ denotes the number of sampling data, $\mathrm{P}$ is the predicted data, $\mathrm{O}$ is the observational data, $\overline{\mathrm{P}}$ is the mean of predicted data, $\overline{\mathrm{O}}$ is the mean of observational data, $\mathrm{u}$ is the zonal wind vector, $\mathrm{v}$ is the meridional wind vector, the asterisk $\left(^{*}\right)$ represents the complex conjugate, Re represents the real part of the complex number, and Im reflects the imaginary part of the complex number.

Table 3 shows the statistical measures between hindcast and in situ observation for $10 \mathrm{~m}$ winds from 2014 to 2016. During the period, the MB for wind speed was in the $0.1 \sim 0.8 \mathrm{~m} / \mathrm{s}$ range at each station, indicating that the model slightly overestimated wind speed. The mean RMSE at each station was $2.20 \mathrm{~m} / \mathrm{s}$. The mean magnitude of the complex correlation was 0.83 and the phase angles were $<10^{\circ}$ except DH. A detailed comparison between the hindcast, observation, and satellite data for $10 \mathrm{~m}$ winds can be found in Kim et al. [41].

Table 3. Statistical evaluation of the hindcast of sea surface wind from 2014 to 2016. The statistics used were Mean Bias (MB), Root-Mean-Square Error (RMSE), Index of Agreement (IOA), Complex Correlation magnitude (CC magnitude), and Complex Correlation phase lag (CC phase lag).

\begin{tabular}{ccccccc}
\hline Name & $\begin{array}{c}\text { MB } \\
(\mathbf{m} / \mathbf{s})\end{array}$ & $\begin{array}{c}\text { RMSE } \\
(\mathbf{m} / \mathbf{s})\end{array}$ & IOA & CC Magnitude & $\begin{array}{c}\text { CC } \\
\text { Phase Lag } \\
\text { (Degree) }\end{array}$ & $\begin{array}{c}\text { Num. of } \\
\text { Pairs }\end{array}$ \\
\hline Donghae (DH) & 0.62 & 2.31 & 0.86 & 0.80 & -11.1 & 15,616 \\
Ulleung (UL) & 0.84 & 2.24 & 0.89 & 0.87 & -5.7 & 16,362 \\
Pohang (PH) & 0.34 & 2.24 & 0.89 & 0.87 & -8.5 & 16,463 \\
Ulleung NE (E01) & 0.23 & 2.01 & 0.91 & 0.81 & -6.5 & 12,983 \\
Ulleung NW (E02) & 0.14 & 2.21 & 0.89 & 0.81 & 2.1 & 14,724 \\
\hline
\end{tabular}

Table 4 shows the statistical measures between the hindcast and in situ data for significant wave height and peak period in the 2014-2016 period. Table 5 also shows the evaluation results, which were limited when the significant wave height was above $2 \mathrm{~m}$. There were no peak period measurements at the buoy stations (DH, UL, PH, E01, and E02), unlike the acoustic Doppler profiler stations (SC, MB, WJ, SR, and YI). The peak period evaluation results in Table 4 were sampled with a significant wave height of $1 \mathrm{~m}$ or more for a comprehensive evaluation. The MB for significant wave height and peak period reflected negative values at most stations, which suggests that the wave model slightly underestimated the wave height. The RMSE and IOA further indicate that the model efficiently reproduced wave height and period.

Table 4. Statistical evaluation of the hindcast of significant wave height and peak period from 2014 to 2016. The statistics used are Mean Bias (MB), Root-Mean-Square Error (RMSE), and Index of Agreement (IOA).

\begin{tabular}{cccccccccc}
\hline & \multicolumn{4}{c}{ Significant Wave Height (m) } & \multicolumn{3}{c}{ Peak Period (s) } \\
\cline { 2 - 9 } Name & Mean & MB & RMSE & IOA & $\begin{array}{c}\text { Num. of } \\
\text { Pairs }\end{array}$ & MB & $\begin{array}{c}\text { RMSE } \\
\text { IOA }\end{array}$ & $\begin{array}{c}\text { Num. of } \\
\text { Pairs }\end{array}$ \\
\hline Donghae (DH) & 1.26 & -0.13 & 0.42 & 0.94 & 17,021 & - & - & - \\
Ulleung (UL) & 1.39 & -0.14 & 0.41 & 0.95 & 16,921 & - & - & - \\
Pohang (PH) & 1.19 & -0.11 & 0.40 & 0.94 & 17,068 & - & - & - & - \\
Ulleung NE (E01) & 1.15 & 0.00 & 0.63 & 0.89 & 14,599 & - & - & - & - \\
Ulleung NW (E02) & 1.26 & -0.05 & 0.43 & 0.94 & 15,726 & - & - & - & - \\
Sokcho (SC) & 0.76 & 0.02 & 0.30 & 0.94 & 13,685 & -0.1 & 1.0 & 0.91 & 2497 \\
Maengbang (MB) & 0.86 & -0.13 & 0.33 & 0.93 & 16,922 & -0.2 & 0.9 & 0.92 & 3353 \\
Wuljin (WJ) & 1.03 & -0.12 & 0.33 & 0.92 & 12,587 & -0.2 & 0.9 & 0.93 & 2743 \\
Sureummal (SR) & 0.89 & -0.03 & 0.30 & 0.94 & 4705 & -0.2 & 0.9 & 0.94 & 1132 \\
Youngil (YI) & 0.76 & -0.18 & 0.34 & 0.89 & 16,416 & -0.1 & 0.9 & 0.94 & 2820 \\
\hline
\end{tabular}


Table 5. Statistical evaluation of the hindcast of significant wave height and peak period from 2014 to 2016. Significant wave height was sampled above $2 \mathrm{~m}$. The statistics used were Mean Bias (MB), Root-Mean-Square Error (RMSE), and Index of Agreement (IOA).

\begin{tabular}{cccccccccc}
\hline & \multicolumn{4}{c}{ Significant Wave Height $(\mathbf{m})$} & \multicolumn{3}{c}{ Peak Period (s) } \\
\cline { 2 - 9 } Name & Mean & MB & RMSE & IOA & $\begin{array}{c}\text { Num. of } \\
\text { Pairs }\end{array}$ & MB & $\begin{array}{c}\text { RMSE } \\
\text { IOA }\end{array}$ & $\begin{array}{c}\text { Num. of } \\
\text { Pairs }\end{array}$ \\
\hline Donghae (DH) & 3.00 & -0.10 & 0.61 & 0.85 & 1993 & - & - & - \\
Ulleung (UL) & 3.09 & -0.25 & 0.60 & 0.86 & 2520 & - & - & - \\
Pohang (PH) & 3.01 & -0.27 & 0.59 & 0.84 & 1561 & - & - & - & - \\
Ulleung NE (E01) & 3.09 & -0.13 & 0.58 & 0.88 & 1554 & - & - & - & - \\
Ulleung NW (E02) & 3.07 & -0.09 & 0.53 & 0.89 & 1799 & - & - & - & - \\
Sokcho (SC) & 2.81 & -0.12 & 0.40 & 0.89 & 485 & 0.0 & 0.7 & 0.94 & 485 \\
Maengbang (MB) & 2.81 & -0.19 & 0.44 & 0.86 & 531 & -0.1 & 0.7 & 0.93 & 531 \\
Wuljin (WJ) & 2.90 & -0.35 & 0.62 & 0.65 & 274 & -0.2 & 0.8 & 0.96 & 274 \\
Sureummal (SR) & 2.94 & -0.35 & 0.56 & 0.76 & 266 & -0.1 & 0.8 & 0.91 & 266 \\
Youngil (YI) & 2.71 & -0.20 & 0.50 & 0.80 & 298 & -0.4 & 0.8 & 0.95 & 298 \\
\hline
\end{tabular}

\subsection{Decadal Trends of Swell-like Waves}

To analyze the long-term trend of swell-like waves, we scrutinized the events with a significant wave height of $2 \mathrm{~m}$ or more, a peak period of $10 \mathrm{~s}$ or more, and a duration of more than $3 \mathrm{~h}$ from the wave hindcast data. Note that if the wave model grid included in the east coast of Korea $\left(35.3^{\circ} \mathrm{N}-38.6^{\circ} \mathrm{N}\right)$ satisfied these criteria, it was classified as a swell-like wave. Figure 4 a shows the number of annual swell-like wave events on the east coast of Korea from 1979 to 2016. In total, 179 cases of swell-like waves were extracted and were found to last for an average of $20 \mathrm{~h}$. Of these, 165 were linked to the passage of low-pressure systems. Eight of them were confirmed as being counted twice with the movement and development of the same cyclone. In six cases, winds occurred at the edges of the Siberian high, regardless of direct ETC intervention. Moreover, 33 events of 165 cyclones were identified as typhoons.

Notably, the events have become more frequent since the 2000s. From 1979 to 2002, an average of 3 swell-like waves occurred, but from 2003 to 2016, an average of 7.7 swell-like waves occurred. Figure $4 \mathrm{~b}$ illustrates the trend of swell-like wave occurrence by month and type. We found that the waves caused by ETCs occurred mainly in November-April, and waves triggered by typhoons occurred intensively in July-October. The results shown in Figure $4 \mathrm{~b}$ are different from those of Figure $3 \mathrm{~b}$. Even if a swell-like wave occurred at the coast, it was not reported unless it caused human loss or property damage. Figure $4 \mathrm{c}$ shows the frequency of swell-like waves caused by ETCs and the trend of the 5 year moving average in December-February. The increased frequency of swell-like waves in the 2000s was due to the significant increase in ETCs, as there were no significant trends in the frequency of swell-like waves caused by typhoons or high-pressure systems.

We extracted low-pressure systems through the cyclone track algorithm and further analyzed the long-term characteristics of cyclones. In total, 10,288 cyclones were extracted from 1979 to 2016, with an average annual occurrence of 270 per year (not shown). The average duration of the cyclones was two days, and the median duration was three days. To investigate the characteristics of the cyclone track, we examined the track density of cyclones from 1979 to 2016 (Figure 5). As seen, there were two distinct regions with the highest frequency of cyclone passage in East Asia. In the regions centered on the southern tip of the Sea of Okhotsk (Oyashio) $\left(50^{\circ} \mathrm{N}, 162^{\circ} \mathrm{E}\right)$ and centered on eastern Mongolia $\left(48^{\circ} \mathrm{N}, 126^{\circ} \mathrm{E}\right)$, track densities were found to be $\sim 0.5$ per day and more than 0.4 per day, respectively. Moreover, the regions with a track density of $>0.1$ per day extend from latitudes $12-24^{\circ} \mathrm{N}$, including the South China Sea to the Sea of Okhotsk. Note that previous studies have concluded that numerous ETCs occurred in the West Siberian Plains, downstream of the Altai-Sayan Mountains (same as Northeast China), the East China Sea, and the Kuroshio-Oyashio extension [42-49]. Some studies have reported that the leeward 
cyclogenesis region downstream of the Altai-Sayan Mountains and the coastal cyclogenesis region in the warm ocean water region of EJS in the East China Sea are the main regions in which East Asian ETC occurs [44,45].

(a)

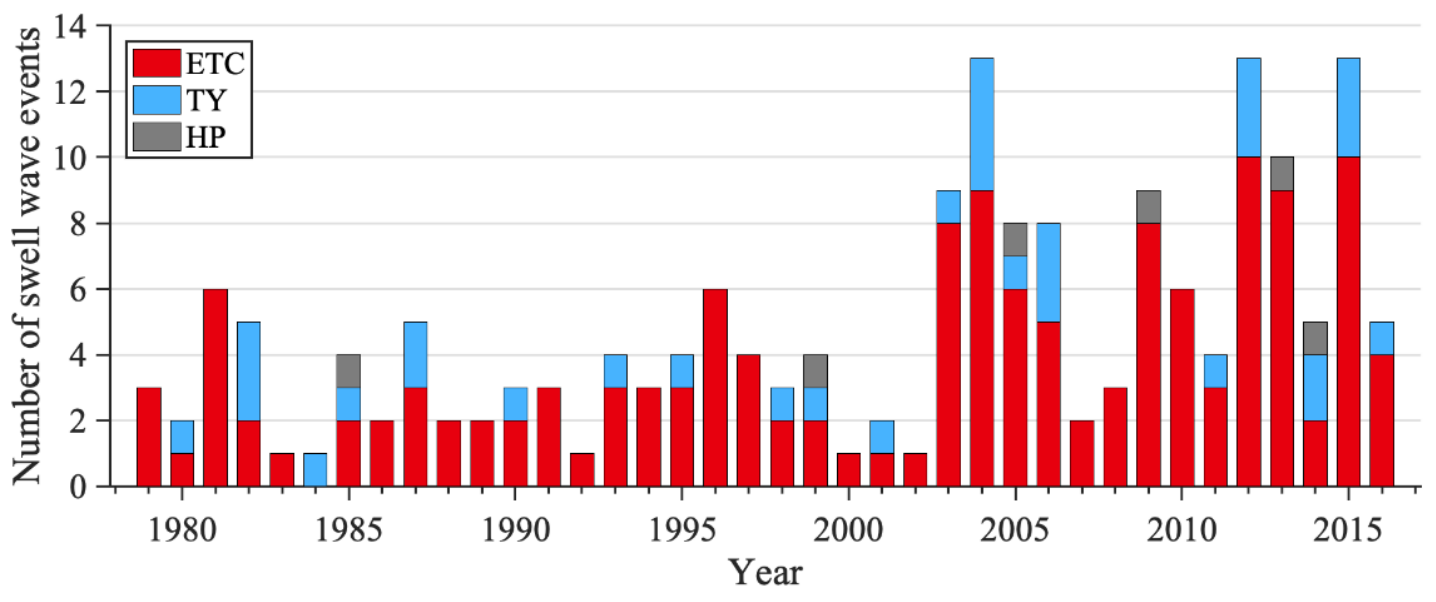

(b)

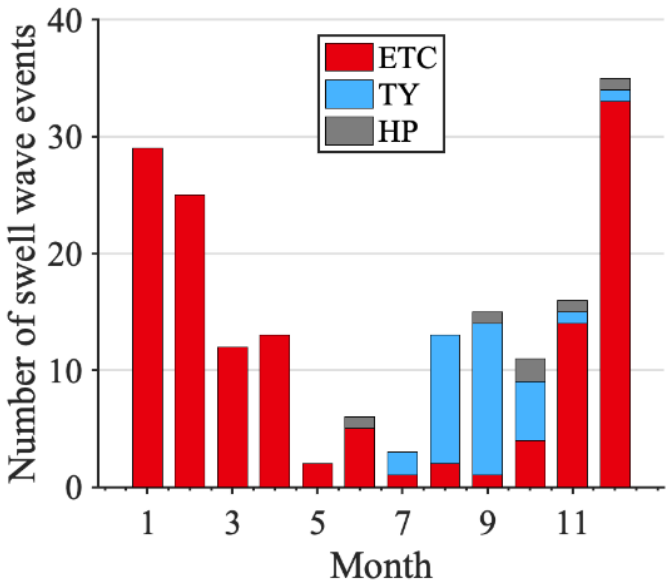

(c)

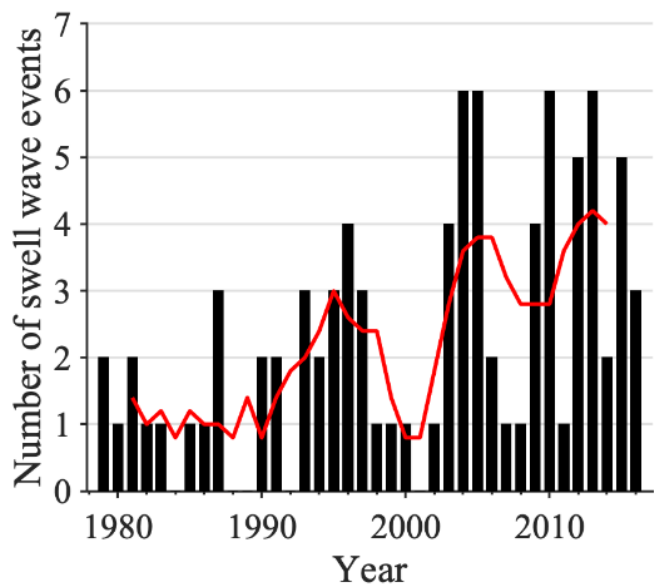

Figure 4. (a) Number of annual swell-like wave occurrences and causative factors including extratropical cyclone (ETC), typhoon (TY), and high-pressure system (HP) based on hindcast data from 1979 to 2016; (b) monthly swell-like wave occurrences and the causative factors; and (c) number of cases resulting from ETC in winter (December-February). The red line in (c) reflects the 5 year moving average.

To elucidate the seasonal pattern of cyclone activity, we reconstructed the cyclone track density in December-February (DJF), March-May (MAM), June-August (JJA), and September-November (SON) from 1979 to 2016. The region with the maximum of TD in DJF is the south of the Kamchatka peninsula. The TD extended in the northeast-southwest direction around this region (Figure $5 b)$. A TD of 0.6 day $^{-1}\left(0.5\right.$ day $\left.^{-1}\right)$ or more was identified in the Kuroshio-Oyashio extension region during the DJF (MAM) (Figure 5d). On the other hand, a TD of 0.5 day $^{-1}$ or more was observed during MAM in Northeast China. Adachi and Kimura [45] reported that the maximum cyclogenesis in DJF occurs from the East China Sea to northeastern Taiwan. Wang et al. [48] also emphasized that the frequency of ETCs occurring in northeastern China peaks in MAM. TD was 0.4 day $^{-1}$ or more in the northeastern part of China and 0.3 day $^{-1}$ or more in the low latitudes of the North Pacific Ocean and the southern tip of the Sea of Okhotsk due to typhoons in JJA (Figure 5d). The frequency of cyclogenesis in northeastern China has decreased, while in the Kuroshio-Oyashio extension region, it was $>0.7$ day $^{-1}$ (Figure 5e). However, the TD remained above 0.2 day $^{-1}$ in the low latitudes of the Northwest Pacific Ocean. 

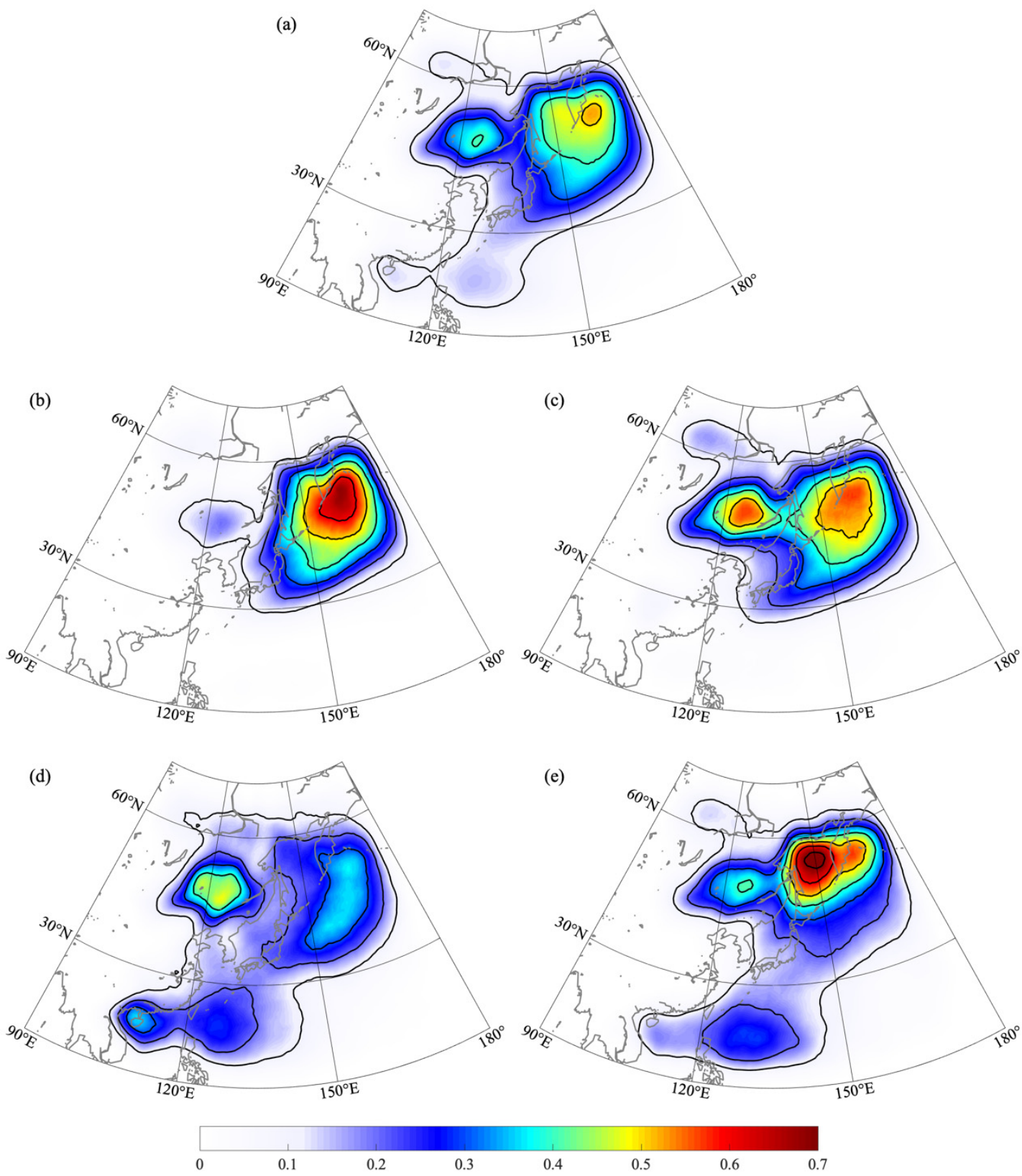

Figure 5. Track density of cyclones from 1979 to 2016. (a) Total, (b) DJF, (c) MAM, (d) JJA, and (e) SON. TD is the relative value of each period.

To analyze the role of cyclones in the occurrence of swell-like waves invading the eastern coast of Korea, the paths and central pressures of 165 ETCs and typhoons related to the occurrence of swell-like waves were reconstructed (Figure 6). Most typhoons moved toward the Sea of Okhotsk along the Korean Peninsula and the Japanese archipelago. ETCs were seemingly intensified from the region of their origin to the west (Figure 6a). Figure 6c displays the count of grid points affected by 132 ETCs and their initial points associated with the occurrence of swell-like waves. Note that we account for the number of ETC passages for all grid points within the outermost isobars in order to consider both size and duration. The occurrences of cyclones linked to swell-like waves on the east coast of Korea were clustered in the East China Sea, EJS, and Kuroshio-Oyashio extension region. It should be noted that the passage of ETCs associated with swell-like waves exhibited a southward shift from the TD, as demonstrated in Figure 5. 
(a)

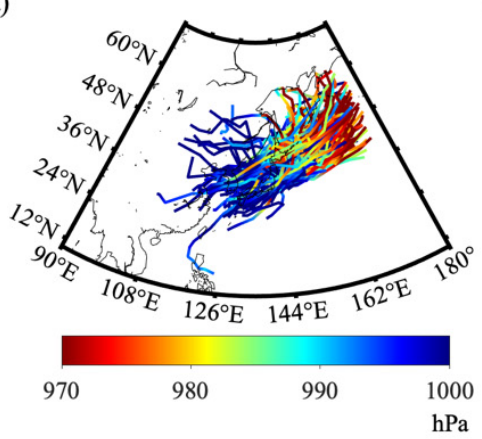

(b)

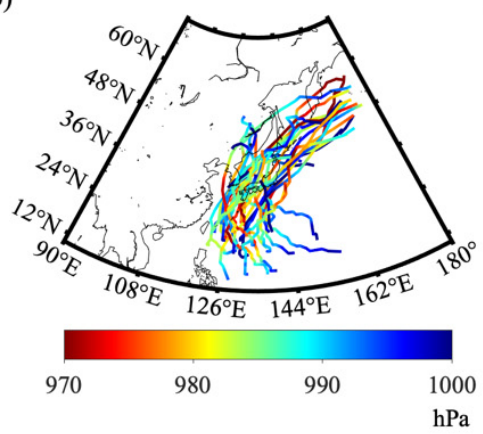

(c)

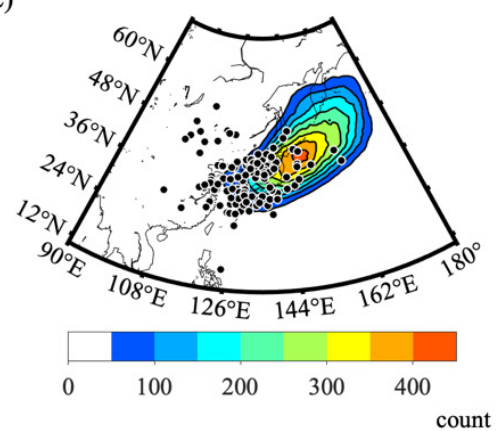

Figure 6. The paths and central pressures of (a) 132 ETCs and (b) 33 typhoons with regard to the occurrence of swell-like waves invading the eastern coast of Korea, and (c) the count of grid points affected by 132 ETCs at the outermost contour (shaded). The black dots represent the initial points of the ETCs.

As shown in Figure 4c, the swell-like wave index, which is a 5 year moving average of the swell-like wave events caused by ETCs in DJF, exhibited a strong interannual variability. Further, a prominent positive trend or abrupt increasing regime shift was observed in the period after 2004. Based on the horizontal correlation map plotting the swell-like wave index and certain variables, a statistically significant atmospheric-oceanic signal can be inferred [50]. Here, we analyze the possible reason for increases in the swell-like wave index by calculating the correlation map of wind activity (Equation (2)). The swell-like wave index is significantly correlated with both the high frequency (2-8 days) and medium-range (9-21 days) wind activity around Korea, EJS, and the southern part of Japan (Figure 7). A statistically significant positive correlation occurred within storm pathways and sites where ETCs caused swell-like waves (Figure 6). Not all cyclones occurring in or passing through this region generate swell-like waves that affect the eastern coast of Korea; however, ETCs with strong wind activity can induce them frequently.

(a) Wind activity (2-8 days)

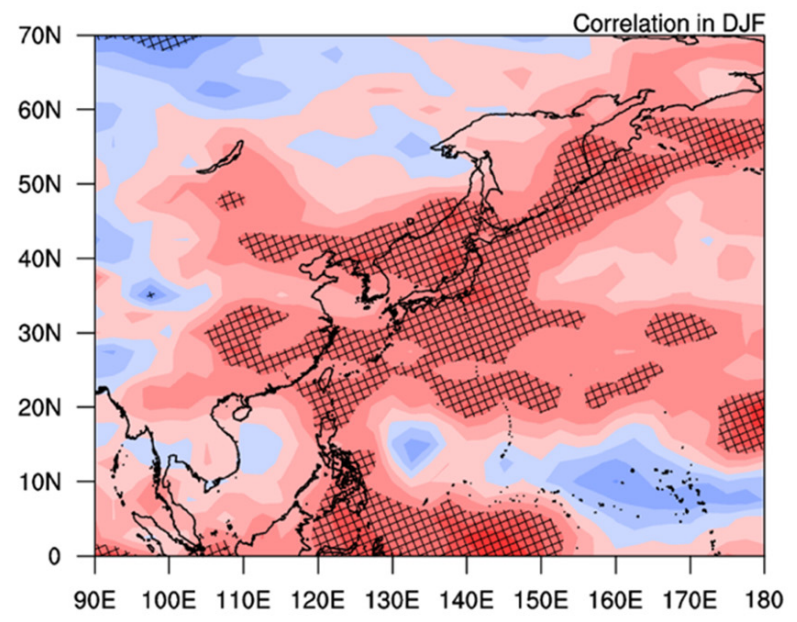

(b) Wind activity (9-21 days)

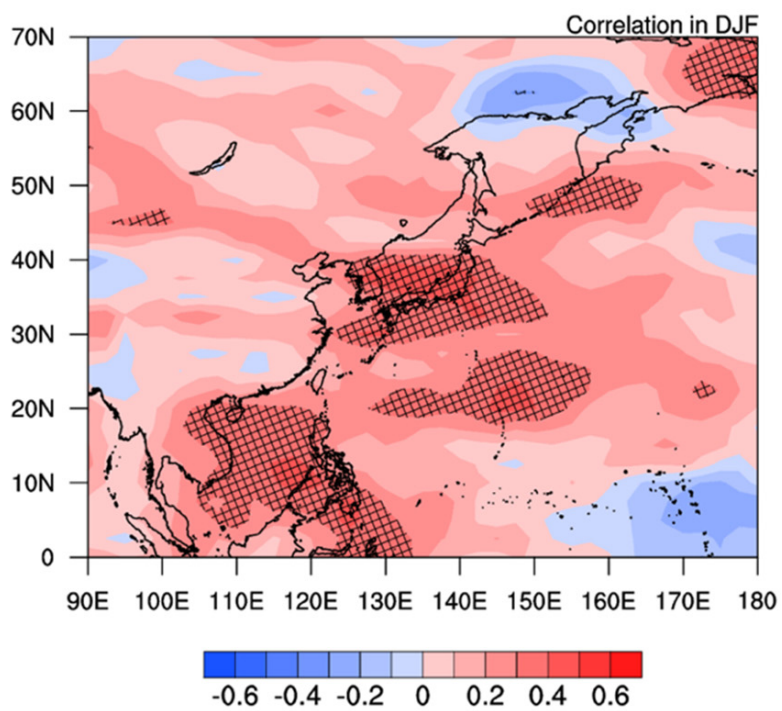

Figure 7. Correlation map of wind activity bandpass-filtered in (a) 2-8 days and (b) 9-21 days against the Korean swell-like wave index in DJF. Hatch denotes $95 \%$ significance region.

The inter-annual time-series of both the 2-8- and 9-21-day bandpass-filtered wind activity averaged over the domain for $130-140^{\circ} \mathrm{E}, 30-40^{\circ} \mathrm{N}$ in DJF are illustrated in Figure 8. To make the anomaly visible, the climatological mean value was removed in each timeseries. In the 2-8 days wind activity index, the inter-annual variability was dominant, but 
the 9-21 days wind activity revealed a strong inter-annual variability with a visible positive trend or regime shift after 2004. The correlation coefficients between the swell-like wave index and both 2-8 and 9-21 days wind activity indices were 0.43 and 0.53 , respectively. The correlation with the $2-8$ days wind index was mainly driven by inter-annual variability, while the contribution of the decadal trend was stronger in the 9-21 days index compared to the inter-annual variation.

(a) Wind activity (2-8 day) in DJF

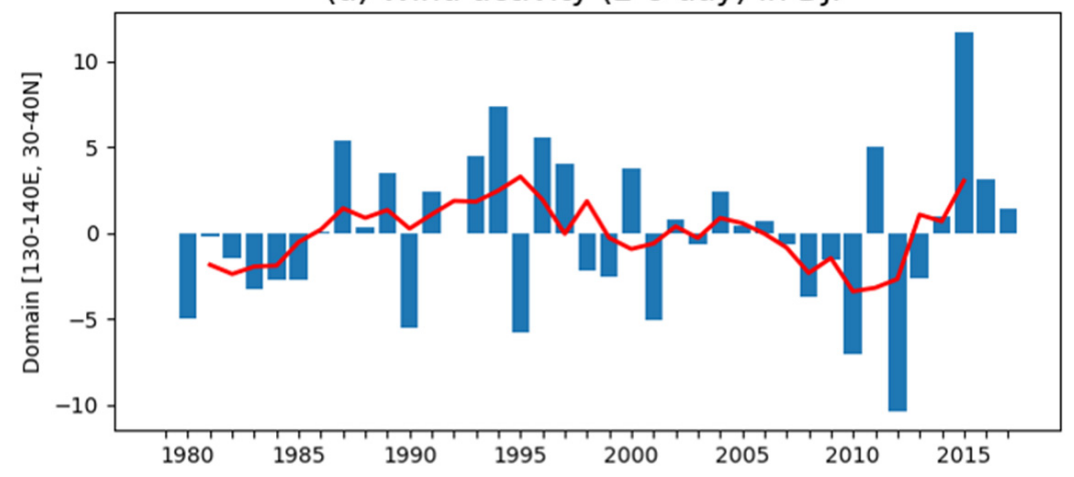

(b) Wind activity (9-21 day) in DJF

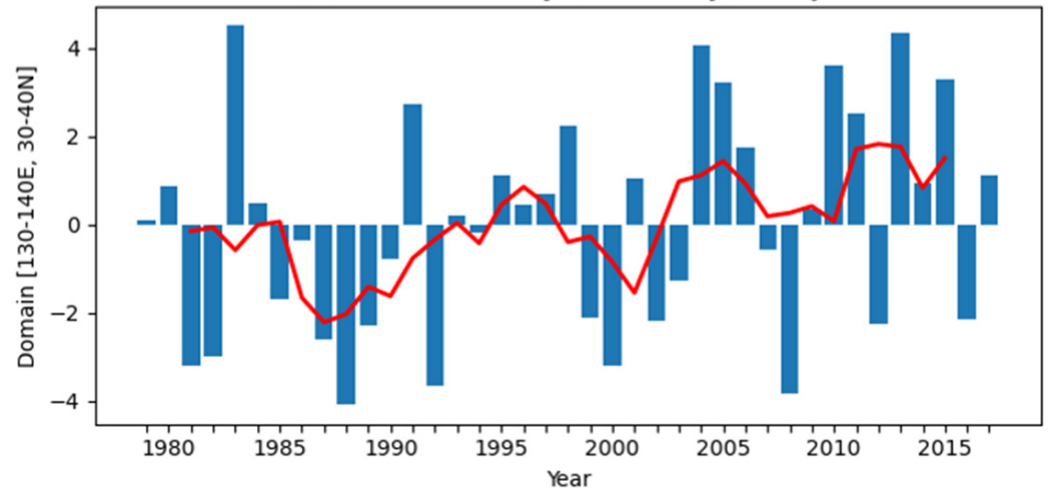

Figure 8. Wind activity filtered in (a) 2-8 and (b) 9-21 days. The time series (red lines) represent the domains averaged in $130-140^{\circ} \mathrm{E}, 30-40^{\circ} \mathrm{N}$.

In general, the ETC activity was affected by the atmospheric internal wave dynamics with the middle latitude jet stream waveguide [51]. ETC activity is known to be modulated by vertical wind shear [52]. The correlation map of swell-like wave index and vertical wind shear (300-925 hPa) in DJF is shown in Figure 9. The negative correlation lies to the east of $40^{\circ} \mathrm{N}, 130^{\circ} \mathrm{E}$.

The negative anomaly of vertical wind shear was locally balanced by the horizontal distribution of surface temperature by the thermal wind relationship [53]. In Figure 10a, the correlation map of $2 \mathrm{~m}$ air temperature in the DJF period is shown against the swell-like wave index. In Figure 10a, a positive $2 \mathrm{~m}$ air temperature correlation was identified around Okhotsk Sea, while a negative temperature correlation was detected over the southern part of the warm region. This reversed meridional gradient of surface temperature can induce weak vertical wind shear to the east of Korea (Figure 9). The $140-160^{\circ} \mathrm{E}, 40-60^{\circ} \mathrm{N}$ domain-averaged $2 \mathrm{~m}$ temperature anomaly in DJF exhibited the positive decadal trend (Figure 10). The correlation of the $2 \mathrm{~m}$ temperature index and swell-like wave index was 0.53. These results imply that slowly eastward-propagating waves (9-21 days), which act as blocking events, occur more frequently under the influence of the negative vertical wind shear anomaly. Consequently, the increasing trend of ETCs seemed to be related to the weak meridional SST gradient to the east of Korea. 


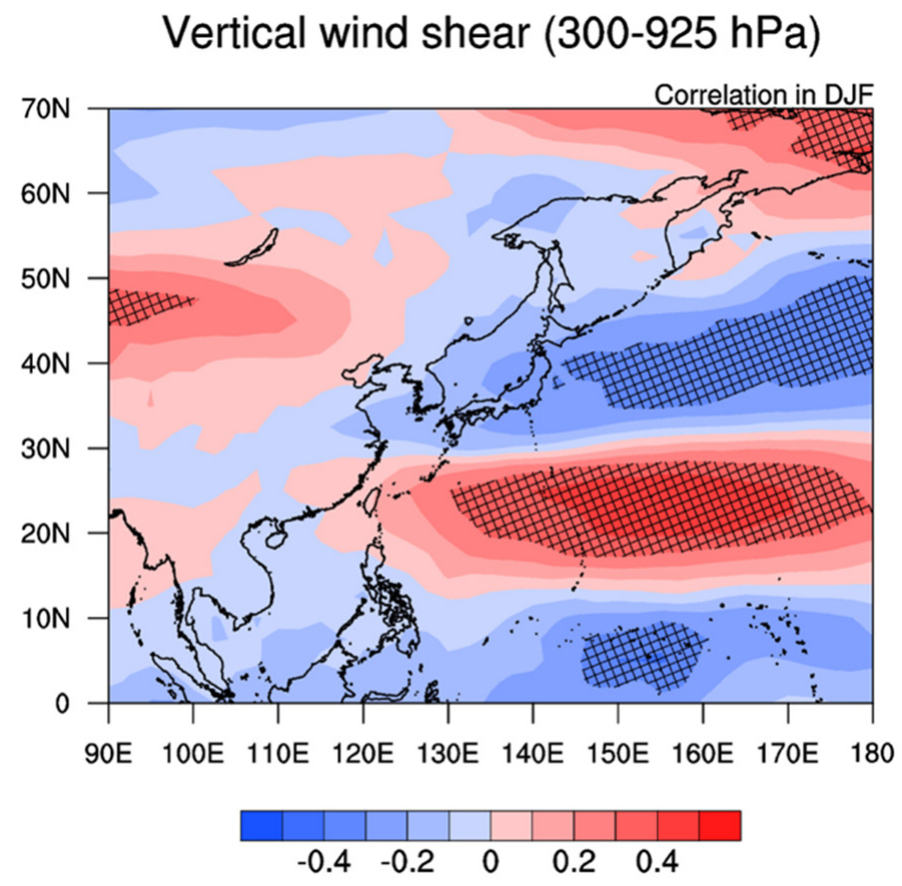

Figure 9. Correlation map of vertical wind shear (300-925 hPa) against Korea swell-like wave index in DJF. Hatch denotes 95\% significant region.

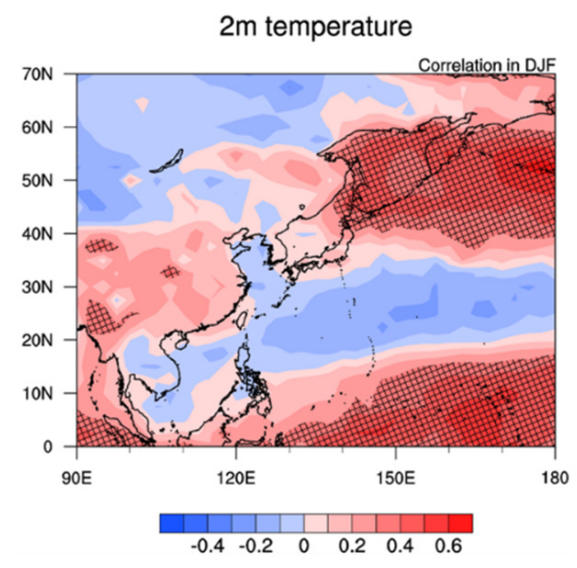

(a)

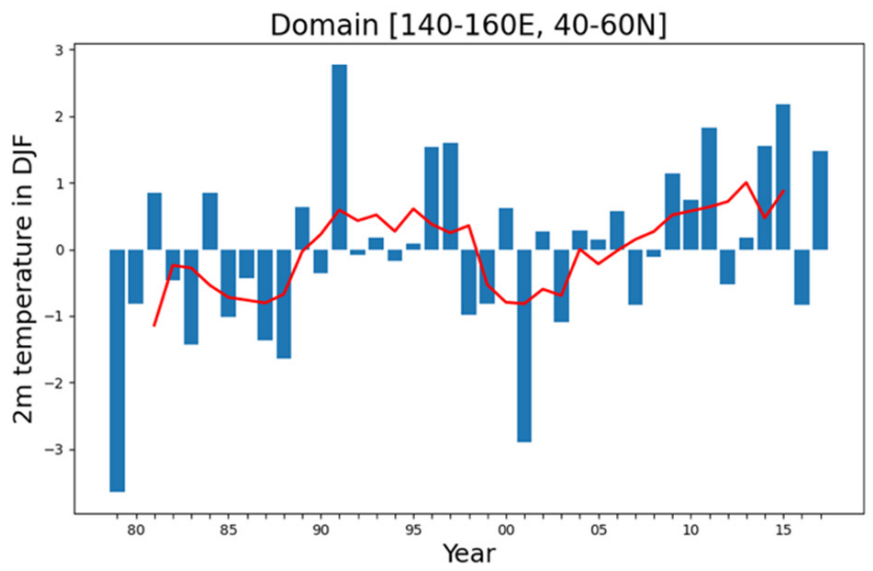

(b)

Figure 10. (a) Correlation map of $2 \mathrm{~m}$ air temperature against the swell-like wave index in DJF. Hatch denotes $95 \%$ significant region. (b) The interannual time series of the domain $\left(140-160^{\circ} \mathrm{E}\right.$, $40-60^{\circ} \mathrm{N}$ )-averaged $2 \mathrm{~m}$ temperature is shown in the left panel.

\section{Discussion}

Many previous studies have reported the occurrence of winter ETC and the corresponding swell-like wave. Our study confirmed that the occurrence of swell-like waves was temporally clustered during December to February. Although ETCs in winter are essential for the generation of swell-like waves, we only considered the wave heights and periods that can affect the coast as swell-like waves to examine their occurrence and determining factors.

Swell-like waves do not occur exclusively, as the low-pressure systems pass through the Korean Peninsula. This is true even if an actual center of low pressure is located in Japan or the Kuroshio-Oyashio extension region. A swell-like wave can occur during conditions that generate a pressure gradient in the East Sea. The track of cyclones and the location of reinforcement are not key factors for swell-like waves, while the atmospheric conditions that can cause a pressure gradient in the EJS are more critical. The tracks of 165 ETCs were 
clustered in the northeast direction from the Yellow Sea to the Aleutian Islands, indicating that ETCs were moving and generating a north-east wind.

The increase in swell-like waves over EJS since the 2000s is an important trend. Although our study only addressed swell-like waves on the east coast of Korea under limited conditions, the number of swell-like waves has been significantly increasing along the other coasts of Korea, Japan, and those of Russia bordering the EJS. Although our study has not elucidated the relationship with climatic factors, the hypothesis that the frequent occurrence of swell-like wave invasions is only temporary should be further examined if the weakening of the north-south temperature gradient continues.

One of the objectives of this study was disaster prevention. We defined the condition of a "swell-like wave that can cause damage," and we presented the long-term trend of swell-like waves according to our own definition. In other words, it is necessary to be careful to compare the results presented in this study with general meteorological and wave climatology. Swell waves are not always a dangerous natural phenomenon and are sometimes used as wave energy in certain areas [54,55]. In Section 3.3, we suggested the cause of the increase trend through the correlation between the swell-like wave index and meteorological factors. This approach can also be applied by substituting a variable other than the swell-like wave index.

The performance of atmospheric and wave hindcasts can affect the accuracy of swelllike wave case classification. Our hindcasts showed sufficient accuracy to distinguish a swell-like wave event that invaded the east coast of Korea (significant wave height of $2 \mathrm{~m}$ or more, a peak period of $10 \mathrm{~s}$ or more, and duration of $3 \mathrm{~h}$ or more) (Tables 4 and 5). However, when using these hindcasts for other purposes, for example, to perform climatology analyses, such as the analyses of wave height and wave energy flux, it is necessary to discuss uncertainties and possible improvements. Our interest is a swell-like wave with a wave period of $5-15 \mathrm{~s}$ (the frequency range is $0.06-0.2 \mathrm{~Hz}$ ). When analyzing the wave spectrum data, in this case, more than $99 \%$ of energy exists at frequencies below $0.4 \mathrm{~Hz}$. Although the results of our numerical model may sometimes show errors in spectrum analysis, there was no significant difference in the comparison of significant wave heights. It is, thus, suitable to perform numerical model calculations with a broader spectrum for more accurate wave analysis. Further, a sensitivity test for some parameters, such as ocean current [56-59] or model parameters [60,61], may also be required. These factors can also increase or decrease the wave height, which can be a critical factor in generating a swell-like wave; however, this study focused only on the relationship between weather and waves.

\section{Conclusions}

The main aim of this study was to examine the long-term trend of occurrence of swell-like waves in the East coast of Korea by using in situ data, high-resolution hindcasts, and reanalysis. As in previous studies, we defined swell-like waves as being waves with a significant wave height of $2 \mathrm{~m}$ or more and a peak period of $10 \mathrm{~s}$ or more and extracted them from the accident cases that occurred between 2005 and 2018. We used high-resolution atmospheric and wave hindcasts to investigate long-term cases of swell-like waves. The WRF model was applied alongside the ECMWF ERA intermediate reanalysis data as input data, while the SWAN model was utilized as a wave model using the output from the WRF model as input data.

We found that the causal synoptic patterns of swell-like waves on the east coast of Korea can be classified into (a) winter extra-tropical cyclones (ETCs), (b) eastwardpropagating cyclones in spring and autumn, the extension of the Siberian High inducing a strong pressure gradient, and (c) typhoons around the EJS. To analyze the characteristics of ETCs that can generate swell-like waves, we tracked all ETCs that occurred between 1979 and 2016 from the cyclone tracking algorithm by using the ECMWF ERA-interim data. We found that the regions of cyclone occurrence and movement were mainly clustered in the east coast of China, the Kuroshio-Oyashio extension area, and the inland of Northeast Asia. This finding aligns with previous studies. The TD of 132 ETCs associated with 
swell-like waves, which occurred on the east coast of China, over the EJS, and over the Kuroshio-Oyashio extension region, exhibited a southward shift from the TD of all the ETCs.

To elucidate the drivers of the decadal increasing trend of swell-like wave events, we analyzed atmospheric synoptic eddy activity. The correlation coefficients between the swell-like wave index and the 2-8 and 9-21 day wind activity indices were 0.43 and 0.53 , respectively. The correlation with the 2-8 days wind activity index was mainly driven by inter-annual variability, while the decadal trend exerted a stronger influence on the 9-21 day index. Therefore, the increasing trend of swell-like waves is related to increasing medium range (9-21 days) wind activity. This activity is associated with the reversed meridional gradient of surface temperature and the consequent negative vertical wind shear anomaly to the east of Korea.

Author Contributions: Conceptualization, S.-H.J. and K.-Y.H.; methodology, S.-H.J., K.-Y.H. and J.-H.S.; software, S.-H.J., K.-Y.H. and J.-Y.C.; validation, S.-H.J.; formal analysis, S.-H.J. and K.-Y.H.; investigation, S.-H.J. and K.-Y.H.; data curation, S.-H.J. and K.-Y.H.; writing-original draft preparation, S.-H.J., K.-Y.H., J.-H.S. and J.-Y.C.; writing-review and editing, S.-H.J., K.-Y.H., J.-H.S., J.-Y.C., Y.-H.J. and J.-I.K.; visualization, S.-H.J. and J.-H.S.; supervision, J.-I.K.; funding acquisition, J.-I.K. All authors have read and agreed to the published version of the manuscript.

Funding: This research was part of the project titled “Improvements of ocean prediction accuracy using numerical modeling and artificial intelligence technology" funded by the Ministry of Oceans and Fisheries, Korea. This work was also supported by KIOST (Grant PEA0042).

Institutional Review Board Statement: Not applicable.

Informed Consent Statement: Not applicable.

Data Availability Statement: The ERA-Interim dataset provided by European Centre for MediumRange Weather Forecasts (ECMWF). Available online: https: / / www.ecmwf.int/en/forecasts / dataset/ ecmwf-reanalysis-interim (accessed on 12 December 2021); The ocean observation buoy data provided by Korea Meteorological Administration (KMA). Available online: https://data.kma.go.kr (accessed on 12 December 2021).

Acknowledgments: We thank the Korea Meteorological Administration and the European Center for Medium-Range Weather Forecasts for the datasets used. We would like to also thank the three anonymous reviewers for their invaluable suggestions and comments.

Conflicts of Interest: The authors declare no conflict of interest.

\section{References}

1. Kitaide, M. On the mechanism and forecasting of the so-called "Yorimawari" Wave. Mar. Rep. Cent. Meteorol. Obs. 1952, 2, $125-151$.

2. Joung, C.H.; Kim, S.S.; Park, S.U.; Min, K.D.; An, H.S. A case study on the extratropical cyclone development on the East Sea. J. Korean Met. Soc. 1984, 20, 1-21.

3. Lee, H.S.; Kim, K.O.; Yamashita, T.; Komaguchi, T.; Mishima, T. Abnormal storm waves in the winter East/Japan Sea: Generation process and hindcasting using an atmosphere-wind wave modelling system. Nat. Hazards Earth Syst. Sci. 2010, 10, 773-792. [CrossRef]

4. Heo, K.Y.; Choi, J.Y.; Jeong, S.H.; Kwon, J.I. Characteristics of High Swell-like Waves on East Coast of Korea Observed by Direct Measurements and Reanalysis Data Sets. J. Coast. Res. 2020, 95, 1433-1437. [CrossRef]

5. Pierson, W.J., Jr.; Moskowitz, L. A proposed spectral form for fully developed wind seas based on the similarity theory of SA Kitaigorodskii. J. Geophys. Res. 1964, 69, 5181-5190. [CrossRef]

6. Collard, F.; Ardhuin, F.; Chapron, B. Monitoring and analysis of ocean swell fields from space: New methods for routine observations. J. Geophys. Res. Earth Surf. 2009, 114, C07023. [CrossRef]

7. Dobson, F.; Perrie, W.; Toulany, B. On the deep-water fetch laws for wind-generated surface gravity waves. Atmos. Ocean 1989, 27, 210-236. [CrossRef]

8. Ebuchi, N.; Kawamura, H.; Toba, Y. Growth of Wind-Waves with Fetch Observed by the Geosat Altimeter in the Japan Sea under Winter Monsoon. J Geophys. Res. Oceans 1992, 97, 809-819. [CrossRef]

9. Utsunomiya, Y.; Okada, H.; Eguchi, I.; Takayama, T.; Nihei, F. A study on the prediction and monitoring system of swell waves. Coast. Res. Cent. 2009, 9, 81-84.

10. Jeong, W.M.; Oh, S.H.; Lee, D.Y. Abnormally high waves on the east coast. J. Korean Soc. Coast. Ocean Eng. 2007, $19,295-302$. 
11. Oh, S.H.; Jeong, W.M.; Lee, D.Y.; Kim, S.I. Analysis of the reason for occurrence of large-height swell-like waves in the east coast of Korea. J. Korean Soc. Coast. Ocean Eng. 2010, 22, 101-111.

12. Geosystem Research. Investigation of Large Swell Waves and Rip Currents and Development of the Disaster Response System (Publification No. 2014-0057); Ministry of Oceans and Fisheries: Sejong, Korea, 2019; pp. 116-122.

13. Jang, J.B.; Yeo, Y.K.; Lee, J.K.; Park, K.S. The analysis and cause tracking method for the swell-generated waves in Korea. In Proceedings of the 2008 Conference of the Korean Association of Ocean Science and Technology Societies, Jeju, Korea, 29 May 2008; pp. 2448-2451.

14. Chen, S.J.; Kuo, Y.H.; Zhang, P.Z.; Bai, Q.F. Climatology of Explosive Cyclones Off the East-Asian Coast. Mon. Weather Rev. 1992, 120, 3029-3035. [CrossRef]

15. Ninomiya, J.; Taka, Y.; Mori, N. Projecting changes in explosive cyclones and high waves around Japan using a mega-ensemble projection. Ocean Eng. 2021, 237, 109634. [CrossRef]

16. Heo, K.Y.; Shim, J.S.; Kwon, J.I.; Jeong, J.Y.; Park, K.S.; Choi, J.W. Abnormal storm waves around the Korean Peninsula: A case study of an extratropical explosive cyclone over East Sea. J. Coast. Res. 2013, 65, 720-725. [CrossRef]

17. Jeong, W.M.; Oh, S.H. Abnormally High Swells Occurred on the East Coast in Recent Several Years. In Proceedings of the 2009 Conference of the Korean Association of Ocean Science and Technology Societies, Changwon, Korea, 28 May 2009; pp. $2119-2122$.

18. Chang, E.K.M.; Lee, S.Y.; Swanson, K.L. Storm track dynamics. J. Clim. 2002, 15, 2163-2183. [CrossRef]

19. Hoskins, B.J.; Hodges, K.I. New perspectives on the Northern Hemisphere winter storm tracks. J. Atmos. Sci. 2002, 59, $1041-1061$. [CrossRef]

20. Madonna, E.; Wernli, H.; Joos, H.; Martius, O. Warm Conveyor Belts in the ERA-Interim Dataset (1979-2010). Part I: Climatology and Potential Vorticity Evolution. J. Clim. 2014, 27, 3-26. [CrossRef]

21. Dee, D.P.; Uppala, S.M.; Simmons, A.J.; Berrisford, P.; Poli, P.; Kobayashi, S.; Andrae, U.; Balmaseda, M.A.; Balsamo, G.; Bauer, P.; et al. The ERA-Interim reanalysis: Configuration and performance of the data assimilation system. Q. J. R. Meteorol. Soc 2011, 137, 553-597. [CrossRef]

22. Skamarock, W.C.; Klemp, J.B.; Dudhia, J.; Gill, D.O.; Barker, D.M.; Wang, W.; Powers, J.G. A Description of the Advanced Research WRF Version 3. NCAR Technical Note-475+ STR; University Corporation for Atmospheric Research: Boulder, CO, USA, 2008.

23. Huang, X. Four-dimensional variational data assimilation for WRF: Formulation and preliminary results. Mon. Weather Rev. 2009, 137, 299-314. [CrossRef]

24. Barker, D.M. The Weather Research and Forecasting Model's Community Variational/Ensemble Data Assimilation System: WRFDA. Bull. Am. Meteorol. Soc. 2012, 93, 831-843. [CrossRef]

25. Hong, S.Y.; Noh, Y.; Dudhia, J. A new vertical diffusion package with an explicit treatment of entrainment processes. Mon. Weather Rev. 2006, 134, 2318-2341. [CrossRef]

26. Niu, G.Y.; Yang, Z.L.; Mitchell, K.E.; Chen, F.; Ek, M.B.; Barlage, M.; Kumar, A.; Manning, K.; Niyogi, D.; Rosero, E. The community Noah land surface model with multiparameterization options (Noah-MP): 1. Model description and evaluation with local-scale measurements. J. Geophys. Res. Atmos. 2011, 116, D12109. [CrossRef]

27. Kain, J.S.; Fritsch, J.M. Convective Parameterization for Mesoscale Models: The Kain-Fritsch Scheme. In The Representation of Cumulus Convection in Numerical Models; Emanuel, K.A., Raymond, D.J., Eds.; American Meteorological Society: Boston, MA, USA, 1993; pp. 165-170.

28. Dudhia, J. Numerical Study of Convection Observed during the Winter Monsoon Experiment Using a Mesoscale Two-Dimensional Model. J. Atmos. Sci. 1989, 46, 3077-3107. [CrossRef]

29. Hong, S.Y.; Lim, J.O.J. The WRF single-moment 6-class microphysics scheme (WSM6). Asia-Pac. J. Atmos. Sci. 2006, 42, 129-151.

30. Booij, N.; Ris, R.C.; Holthuijsen, L.H. A third-generation wave model for coastal regions: 1. Model description and validation. J. Geophys. Res. Oceans 1999, 104, 7649-7666. [CrossRef]

31. Intergovernmental Oceanographic Commission (IOC). BODC: Centenary Edition of the GEBCO Digital Atlas [CD-ROM]; British Oceanographic Data Centre: Liverpool, UK, 2003.

32. Hasselmann, K.F.; Barnett, T.P.; Bouws, E.; Carlson, H.; Cartwright, D.E.; Eake, K.; Euring, J.; Gicnapp, A.; Hasselmann, D.; Kruseman, P. Measurements of wind-wave growth and swell decay during the Joint North Sea Wave Project (JONSWAP). Ergaenzungsh. Dtsch. Hydrogr. Z. 1973, 8, 1-95.

33. Flaounas, E.; Kotroni, V.; Lagouvardos, K.; Flaounas, I. CycloTRACK (v1.0)—Tracking winter extratropical cyclones based on relative vorticity: Sensitivity to data filtering and other relevant parameters. Geosci. Model Dev. 2014, 7, 1841-1853. [CrossRef]

34. Lu, C.H. A Modified Algorithm for Identifying and Tracking Extratropical Cyclones. Adv. Atmos. Sci. 2017, 34, 909-924. [CrossRef]

35. Grise, K.M.; Son, S.W.; Gyakum, J.R. Intraseasonal and Interannual Variability in North American Storm Tracks and Its Relationship to Equatorial Pacific Variability. Mon. Weather Rev. 2013, 141, 3610-3625. [CrossRef]

36. Ren, H.L.; Jin, F.F.; Kug, J.S.; Zhao, J.X.; Park, J. A kinematic mechanism for positive feedback between synoptic eddies and NAO. Geophys. Res. Lett. 2009, 36, L11709. [CrossRef]

37. O'Reilly, C.H.; Minobe, S.; Kuwano-Yoshida, A. The influence of the Gulf Stream on wintertime European blocking. Clim. Dyn. 2015, 47, 1545-1567. [CrossRef]

38. Willmott, C.J. On the validation of models. Phys. Geogr. 1981, 2, 184-194. [CrossRef]

39. Willmott, C.J. Some comments on the evaluation of model performance. Bull. Am. Meteorol. Soc. 1982, 63, 1309-1313. [CrossRef]

40. Kundu, P.K. Ekman veering observed near the ocean bottom. J. Phys. Oceanogr. 1976, 6, 238-242. [CrossRef] 
41. Kim, H.J.; Heo, K.Y.; Kim, N.H.; Kwon, J.I. Hindcasts of Sea Surface Wind around the Korean Peninsula Using the WRF Model: Added Value Evaluation and Estimation of Extreme Wind Speeds. Atmosphere 2021, 12, 895. [CrossRef]

42. Chung, Y.S.; Hage, K.D.; Reinelt, E.R. On lee cyclogenesis and airflow in the Canadian Rocky Mountains and the East Asian Mountains. Mon. Weather Rev. 1976, 104, 879-891. [CrossRef]

43. Whittaker, L.; Horn, L. Northern Hemisphere extratropical cyclone activity for four mid-season months. J. Climatol. 1984, 4, 297-310. [CrossRef]

44. Chen, S.J.; Kuo, Y.H.; Zhang, P.Z.; Bai, Q.F. Synoptic Climatology of Cyclogenesis over East-Asia, 1958-1987. Mon. Weather Rev. 1991, 119, 1407-1418. [CrossRef]

45. Adachi, S.; Kimura, F. A 36-year climatology of surface cyclogenesis in East Asia using high-resolution reanalysis data. Sola 2007, 3, 113-116. [CrossRef]

46. Zhang, Y.X.; Ding, Y.H.; Li, Q.P. A Climatology of Extratropical Cyclones over East Asia During 1958-2001. Acta Meteorol. Sin. 2012, 26, 261-277. [CrossRef]

47. Chen, L.; Tan, B.K.; Kvamsto, N.G.; Johannessen, O.M. Wintertime cyclone/anticyclone activity over China and its relation to upper tropospheric jets. Tellus A Dyn. Meteorol. Oceanogr. 2014, 66, 21889. [CrossRef]

48. Wang, X.M.; Zhai, P.M.; Wang, C.C. Variations in extratropical cyclone activity in northern East Asia. Adv. Atmos. Sci. 2009, 26, 471-479. [CrossRef]

49. Lee, J.; Son, S.W.; Cho, H.O.; Kim, J.; Cha, D.H.; Gyakum, J.R.; Chen, D. Extratropical cyclones over East Asia: Climatology, seasonal cycle, and long-term trend. Clim. Dyn. 2019, 54, 1131-1144. [CrossRef]

50. Seo, K.H.; Son, J.H.; Lee, J.Y.; Park, H.S. Northern East Asian monsoon precipitation revealed by air mass variability and its prediction. J. Clim. 2015, 28, 6221-6233. [CrossRef]

51. Wirth, V.; Riemer, M.; Chang, E.K.M.; Martius, O. Rossby Wave Packets on the Midlatitude Waveguide-A Review. Mon. Weather Rev. 2018, 146, 1965-2001. [CrossRef]

52. Sampe, T.; Nakamura, H.; Goto, A.; Ohfuchi, W. Significance of a midlatitude SST frontal zone in the formation of a storm track and an eddy-driven westerly jet. J. Clim. 2010, 23, 1793-1814. [CrossRef]

53. Holton, J. An Introduction to Dynamic Meteorology, 2nd ed.; International Geophysics Series; Academic Press: New York, NY, USA, 1979; Volume 23.

54. Semedo, A.; Vettor, R.; Breivik, Ø.; Sterl, A.; Reistad, M.; Soares, C.G.; Lima, D. The wind sea and swell waves climate in the Nordic seas. Ocean Dyn. 2015, 65, 223-240. [CrossRef]

55. Christakos, K.; Varlas, G.; Cheliotis, I.; Spyrou, C.; Aarnes, O.J.; Furevik, B.R. Characterization of wind-sea-and swell-induced wave energy along the Norwegian coast. Atmosphere 2020, 11, 166. [CrossRef]

56. Ardhuin, F.; Roland, A.; Dumas, F.; Bennis, A.-C.; Sentchev, A.; Forget, P.; Wolf, J.; Girard, F.; Osuna, P.; Benoit, M. Numerical wave modeling in conditions with strong currents: Dissipation, refraction, and relative wind. J. Phys. Oceanogr. 2012, 42, 2101-2120. [CrossRef]

57. Ardhuin, F.; Gille, S.T.; Menemenlis, D.; Rocha, C.B.; Rascle, N.; Chapron, B.; Gula, J.; Molemaker, J. Small-scale open ocean currents have large effects on wind wave heights. J. Geophys. Res. Oceans 2017, 122, 4500-4517. [CrossRef]

58. Onorato, M.; Proment, D.; Toffoli, A. Triggering rogue waves in opposing currents. Phys. Rev. Lett. 2011, 107, 184502. [CrossRef] [PubMed]

59. Christakos, K.; Björkqvist, J.-V.; Breivik, Ø.; Tuomi, L.; Furevik, B.R.; Albretsen, J. The impact of surface currents on the wave climate in narrow fjords. Ocean Model. 2021, 168, 101894. [CrossRef]

60. Van der Westhuysen, A.J.; Zijlema, M.; Battjes, J.A. Nonlinear saturation-based whitecapping dissipation in SWAN for deep and shallow water. Coast. Eng. 2007, 54,151-170. [CrossRef]

61. Christakos, K.; Björkqvist, J.-V.; Tuomi, L.; Furevik, B.R.; Breivik, Ø. Modelling wave growth in narrow fetch geometries: The white-capping and wind input formulations. Ocean Model. 2021, 157, 101730. [CrossRef] 